\title{
Secisbp2 Is Essential for Embryonic Development and Enhances Selenoprotein Expression
}

\author{
Sandra Seeher, ${ }^{1,2}$ Tarik Atassi, ${ }^{3}$ Yassin Mahdi,, Bradley A. Carlson, ${ }^{4}$ Doreen Braun,,2 Eva K. Wirth, \\ Marc O. Klein, ${ }^{5}$ Nathalie Reix, ${ }^{6}$ Angela C. Miniard, ${ }^{3}$ Lutz Schomburg, ${ }^{1}$ Dolph L. Hatfield, ${ }^{4}$ \\ Donna M. Driscoll, ${ }^{3}$ and Ulrich Schweizer ${ }^{1,2}$
}

\begin{abstract}
Aims: The selenocysteine insertion sequence (SECIS)-binding protein 2 (Secisbp2) binds to SECIS elements located in the $3^{\prime}$-untranslated region of eukaryotic selenoprotein mRNAs. Selenoproteins contain the rare amino acid selenocysteine (Sec). Mutations in SECISBP2 in humans lead to reduced selenoprotein expression thereby affecting thyroid hormone-dependent growth and differentiation processes. The most severe cases also display myopathy, hearing impairment, male infertility, increased photosensitivity, mental retardation, and ataxia. Mouse models are needed to understand selenoprotein-dependent processes underlying the patients' pleiotropic phenotypes. Results: Unlike tRNA ${ }^{[\mathrm{Ser}] \mathrm{Sec}}$-deficient embryos, homozygous Secisbp2-deleted embryos implant, but fail before gastrulation. Heterozygous inactivation of Secisbp 2 reduced the amount of selenoprotein expressed, but did not affect the thyroid hormone axis or growth. Conditional deletion of Secisbp2 in hepatocytes significantly decreased selenoprotein expression. Unexpectedly, the loss of Secisbp2 reduced the abundance of many, but not all, selenoprotein mRNAs. Transcript-specific and gender-selective effects on selenoprotein mRNA abundance were greater in Secisbp2-deficient hepatocytes than in $\mathrm{tRNA}^{[\mathrm{Ser}] \mathrm{Sec}}$-deficient cells. Despite the massive reduction of Diol and Seppl mRNAs, significantly more corresponding protein was detected in primary hepatocytes lacking Secisbp2 than in cells lacking tRNA ${ }^{[\mathrm{Ser}] \mathrm{Sec}}$. Regarding selenoprotein expression, compensatory nuclear factor, erythroid-derived, like 2 (Nrf2)-dependent gene expression, or embryonic development, phenotypes were always milder in Secisbp2-deficient than in tRNA ${ }^{[\mathrm{Ser}] \mathrm{Sec}}$-deficient mice. Innovation: We report the first Secisbp2 mutant mouse models. The conditional mutants provide a model for analyzing Secisbp2 function in organs not accessible in patients. Conclusion: In hepatocyte-specific conditional mouse models, Secisbp2 gene inactivation is less detrimental than tRNA ${ }^{[\mathrm{Ser}] \mathrm{Sec}}$ inactivation. A role of Secisbp2 in stabilizing selenoprotein mRNAs in vivo was uncovered. Antioxid. Redox Signal. 21, 835-849.
\end{abstract}

\section{Introduction}

$\mathbf{N}$ ATURALLY OCCURRING EXPANSIONS to the genetic code rely on the recoding of stop codons. Selenocysteine (Sec) is the 21 st proteinogenic amino acid and is present in all three domains of life. Its incorporation into the protein re- quires a complex machinery of cis- and trans-acting factors (24). Messenger RNAs coding for selenoproteins contain the opal codon UGA at the position of Sec insertion and a stemloop structure called the selenocysteine insertion sequence (SECIS) element $(3,61)$. In a bioinformatic genome-wide search for SECIS elements associated with in-frame UGA

\footnotetext{
${ }^{1}$ Institut für Experimentelle Endokrinologie, Charité-Universitätsmedizin Berlin, Berlin, Germany.

${ }^{2}$ Institut für Biochemie und Molekularbiologie, Rheinische Friedrich-Wilhelms-Universität Bonn, Bonn, Germany.

${ }^{3}$ Department of Cellular and Molecular Medicine, Lerner Research Institute, Cleveland Clinic, Cleveland, Ohio.

${ }^{4}$ Molecular Biology of Selenium Section, Laboratory of Cancer Prevention, Center for Cancer Research, National Cancer Institute, National Institutes of Health, Bethesda, Maryland.

${ }^{5}$ Service D'Endocrinologie, Centre Hospitalier et Universitaire de Nancy, Nancy, France.

${ }^{6}$ Laboratoires d'Explorations Fonctionelles par les Isotopes, Hôpitaux Universitaires de Strasbourg, ICube UMR 7357, Université de Strasbourg, CNRS, Strasbourg, France.
} 


\section{Innovation}

Interest in the selenocysteine insertion sequence (SECIS)binding protein 2 (Secisbp2) is manifold. Since Secisbp2 plays a central role in $\mathrm{UGA} / \mathrm{Sec}$ recoding and selenoprotein expression, the study of its molecular biology will ultimately lead to a better insight into translation in general and selenoprotein translation in particular. Second, congenital SECISBP2 deficiency causes a syndrome of growth retardation that has been defined as an atypical form of resistance to the thyroid hormone. We provide the first mouse models that allow us to dissect the roles of Secisbp2 in vivo. Finally, mutations in SECISBP2 demonstrate the fundamental effects of selenoproteins on human health, including immunological, metabolic, and neurological processes.

codons, 25 and 24 genes encoding selenoproteins were identified in the human and mouse genomes, respectively (29). In eubacteria, the SECIS element is located immediately downstream to the UGA in the coding region, while in eukaryotes, it is located in the $3^{\prime}$-untranslated region. In bacteria, a specific translation elongation factor, SelB, binds Sec-tRNA ${ }^{[\mathrm{Ser}] \mathrm{Sec}}$ and interacts with the SECIS element (2). These two functions are served by two proteins in mammals, elongation factor Sec (EF-Sec) and SECIS-binding protein 2 (Secisbp2) $(17,22)$. In all domains of life, Sec biosynthesis occurs on its tRNA ${ }^{[\operatorname{Ser}] \operatorname{Sec}}(31,57,60)$.

Secisbp 2 was purified and cloned based on its ability to bind to SECIS elements in vitro (17). The protein contains an RNA-binding module, the L7Ae domain, which interacts with kink-turn RNA structures such as the one found in the SECIS core that contains a pair of non-Watson-Crick base pairs $(30,54)$. Secisbp 2 facilitates Sec incorporation by binding to the SECIS element, promoting recruitment of EFSec and interacting with the ribosome $(10,18)$. Several other SECIS-binding proteins have since been identified. These include L30 (Rp130), which is a component of the UGA recoding machinery (14), YB1 (48), NSEP1 (47), eIF4a3 (9), and nucleolin $(33,56)$, which play roles in regulating UGA recoding. In addition, Secisbp2L binds to SECIS elements, but does not support Sec incorporation (19) [reviewed in Seeher et al. (44)].

Mutations in SECISBP2 were first identified in a family with several children exhibiting a delay in linear growth and bone age. In addition, these patients manifested slightly elevated total thyroxine $\left(\mathrm{T}_{4}\right)$, low tri-iodothyronine $\left(\mathrm{T}_{3}\right)$, high reverse $\mathrm{T}_{3}$, and high plasma thyroid-stimulating hormone (TSH) as well as abnormal TSH suppression tests that suggested impaired thyroid hormone metabolism (21). Thyroid hormones are subject to deiodinating reactions catalyzed by deiodinases, a family of selenoenzymes (4). By comparison, deiodinase gene (Diol) targeted mice show increased reverse $\mathrm{T}_{3}$ (39), while Dio2 deficiency leads to high $\mathrm{T}_{4}$ and $\mathrm{TSH}$ (38). Indeed, Dio deficiency, along with reduced expression of selenoprotein P (Sepp) and glutathione peroxidases (Gpx), pointed to a general defect in selenoprotein mRNA translation, since Dio2 mRNA levels were normal in fibroblasts from these patients (21). Similarly, abnormal thyroid function tests led to the identification of new patients carrying several homozygous and compound heterozygous mutations in SECISBP2 (20). Other mutations are apparently more disruptive for selenoprotein biosynthesis and lead to additional symptoms like myopathy [similar to selenoprotein $\mathrm{N}$ deficiency (34)], abnormal gait (1), bilateral hearing loss, male infertility, increased photosensitivity, shortened telomere length, and compromised immune function along with abnormal glucose metabolism (40). Mutations in SECISBP2 affect SECIS binding, underlining the importance of SECISBP2 for selenoprotein biosynthesis via SECIS interactions $(1,8)$.

The many roles of selenoproteins in mammalian health are revealed by phenotypes of mouse models deficient for individual selenoproteins or with inefficient selenoprotein mRNA translation, as well as by human congenital disorders of selenoprotein expression $(16,42)$. To study the role of Secisbp2 in tissues, organs, and whole organisms, mouse models are needed that allow for biochemical investigations in tissues not accessible in human patients. We describe here the first constitutive and conditional mouse models for $\mathrm{Se}$ cisbp 2 and compare selenoprotein expression in these with our earlier work on similar mouse models lacking tRNA ${ }^{[\mathrm{Ser}] \mathrm{Sec}}$.

\section{Results \\ Constitutive Secisbp2 gene targeting}

Secisbp 2 gene targeting followed a knockout-first strategy (Fig. 1A) allowing for both classical gene knockout and Cre recombinase-mediated conditional gene ablation. Intercrosses of Secisbp2 $2^{+/-}$mice yielded no live Secisbp2 $2^{-/-}$ offspring, but many resorbed conceptuses (Table 1). Dissection of Secisbp $2^{-/-}$embryos demonstrated developmental retardation by embryonic day 8 (E8) (Fig. 1B). Whereas control embryos had progressed to TS12 (somites 1-7, first branchial arch develops, beginning of heart formation), $\mathrm{Se}$ cisbp $2^{-/-}$embryos are arrested in TS7, which is characterized by implantation of the conceptus and formation of the egg cylinder. Thus, Secisbp $2^{-/-}$embryos failed after implantation, but developed further than $\mathrm{tRNA}^{[\mathrm{Ser}] \mathrm{Sec}}$-deficient embryos that only reached the morulae or blastocyst stage (E3.5; TS2-3) and failed to implant (6).

SECISBP2-mutations in humans are associated with delayed bone development, growth defects, and abnormal thyroid hormone constellations. Heterozygous Secisbp $2^{+/-}$ mice of both sexes exhibit the same body weight and tail length as Secisbp2 ${ }^{+/+}$litter mates (Supplementary Fig. S1; Supplementary Data are available online at www.liebertpub .com/ars). Serum T 4 (Fig. 1C), T 3 (Fig. 1D), or TSH (Fig. 1E) remained normal. Secisbp2 protein levels are substantially reduced in the liver, kidney, brain, and testis (Fig. 1F). Serum $\mathrm{Se}$, which is mainly determined by hepatically released Sepp, was significantly diminished in Secisbp $2^{+/-}$mice (Fig. 1G). Hepatic cytosolic Gpx and thioredoxin reductase (Txnrd) activities were not changed (Fig. 1H, I), while the testicular Gpx4 protein was significantly reduced (Fig. 1J). The highest levels of the Secisbp2 protein are found in the testis, where it is believed to support high Gpx4 expression, a sperm structural protein. Even in the heterozygous mutants, we did not observe reduced fertility of Secisbp $2^{+/-}$males consistent with earlier findings in heterozygous $G p x 4^{+/-}$mice (37). It may be of future interest to explore whether Secisbp $2^{+/-}$ mice are vulnerable to dietary Se restriction. 

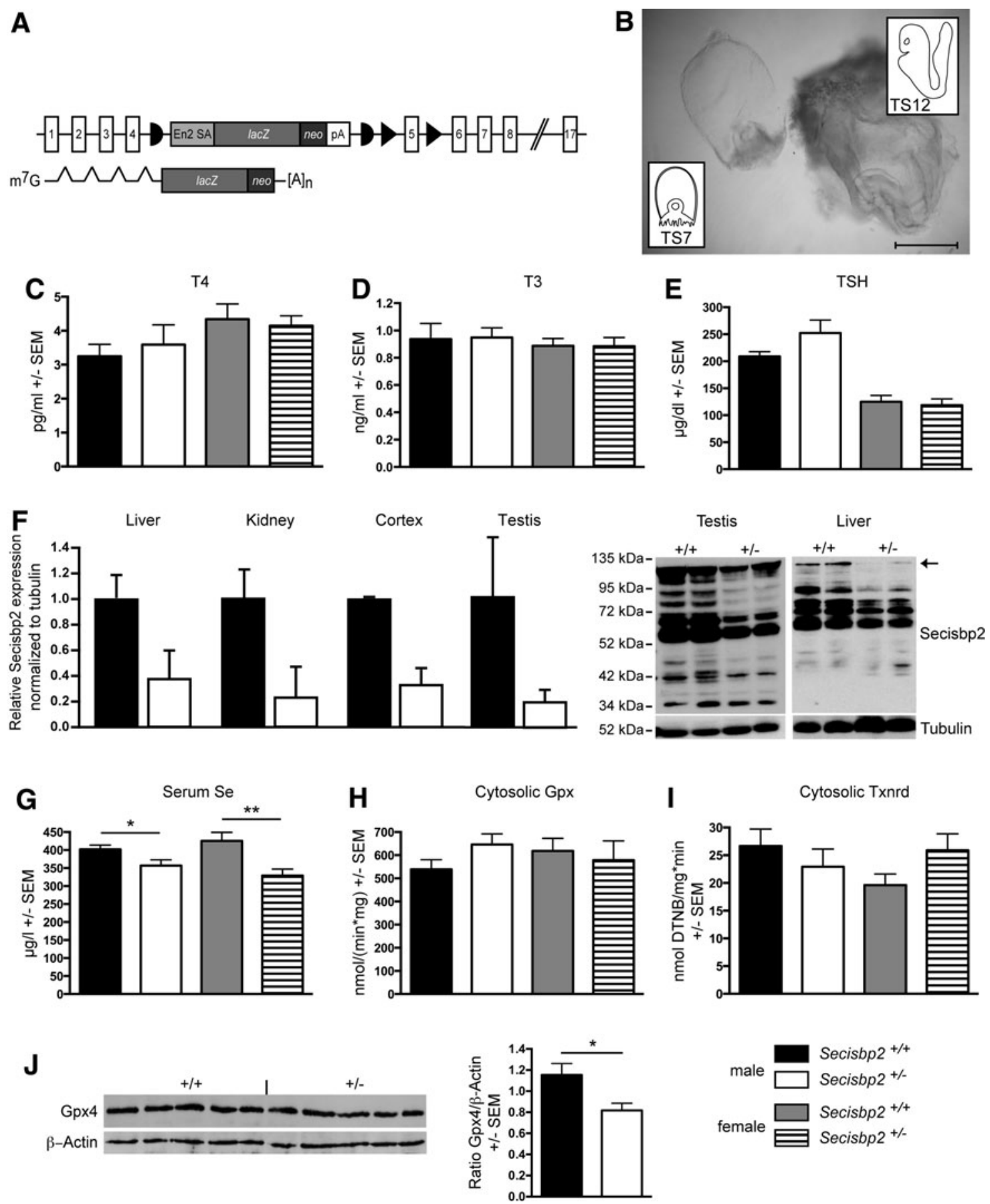

FIG. 1. Gene targeting of Secisbp2. (A) Structure of the targeted Secisbp2 allele and mRNA after splicing. Insertion of a FRT-flanked gene-trap cassette containing an En2 splice acceptor (En2 SA), in-frame lacZ/neo reporter/selection cassette, and polyadenylation signal. The targeted allele produces a fusion transcript that terminates after exon 4 . FRT sites are denoted as half circles and loxP sites as triangles. (B) Embryos at embryonic day 8.5. The homozygous Secisbp2 ${ }^{-1-}$ embryo was developmentally arrested at the Theiler stage 7 (TS7). The control embryo reached the appropriate TS12. Insets: Schematic drawings of TS7 and TS12 embryos. (C) Serum total $\mathrm{T}_{4}$ levels, (D) total $\mathrm{T}_{3}$ levels, (E) serum TSH were not altered in Secisbp2 $2^{+-}$mice. (F) Western blot for Secisbp2 shows reduced protein levels in several organs of Secisbp2 $2^{+/-}$ mice. (G) Serum Se was diminished in Secisbp $2^{+/-}$mice. (H) Hepatic cytosolic Gpx activity was not significantly changed in Secisbp $2^{+/-}$mice. (I) Hepatic cytosolic Txnrd activity determined with the DTNB assay. (J) Testicular Gpx4 protein expression was reduced in Secisbp $2^{+/-}$mice. Secisbp $2^{+/+}$and Secisbp $2^{+/-}$mice were analyzed at the age of 2 to 5 months. $* p<0.05$; $* * p<0.01$; Student's $t$-test. $(n=4-6$ for all groups.). Scale bar $=500 \mu \mathrm{m}$. DTNB, 5,5'-dithiobis(2-nitrobenzoic acid); Gpx, glutathione peroxidase; Secisbp2, selenocysteine insertion sequence-binding protein 2; $\mathrm{T}_{3}$, tri-iodothyronine; $\mathrm{T}_{4}$, thyroxine; $\mathrm{TSH}$, thyroid-stimulating hormone; Txnrd, thioredoxin reductase. 
Table 1. Genotype Analysis of $S$ ECISBP $2^{+/-}$ AND $S E C I S B P 2^{+/ \Delta 5}$ Intercross Progeny

\begin{tabular}{lcccc}
\hline & \multicolumn{4}{c}{ Genotype $^{\mathrm{a}}$} \\
\cline { 2 - 4 } Age & $+/+$ & $+/-$ & $-/-$ & Resorption \\
\hline 3 weeks & 32 & 75 & 0 & N/A \\
$13.5 \mathrm{dpc}$ & 15 & 35 & 3 & 15 \\
$9.5 \mathrm{dpc}$ & 7 & 18 & 7 & 7 \\
\hline \multirow{5}{*}{ Genotype $^{\mathrm{b}}$} \\
& $+/+$ & $+/ \Delta 5$ & $45 / \Delta 5$ & \\
\hline 3 weeks & 26 & 45 & 0 & N/A \\
\hline
\end{tabular}

${ }^{a}$ Genotyping of Secisbp $2^{+/-}$intercrosses 3 weeks after birth yielded no live Secisbp $2^{-1-}$ offspring. Analysis of embryos from day 9.5 post coitum (dpc) detected several resorbed structures, which were identified as Secisbp $2^{-1-}$. Genotyping resorptions on $13.5 \mathrm{dpc}$ was more complicated because of the more advanced stage of resorption. Most potential Secisbp2 $2^{-/-}$embryos were likely assigned to Secisbp $2^{+1-}$ due to contamination with maternal tissue.

${ }^{\mathrm{b}}$ Genotyping of Secisbp $2^{+/ \Delta 5}$ intercrosses 3 weeks after birth yielded no live Secisbp $2^{\Delta 5 / \Delta 5}$ offspring. Secisbp $2^{+/ \mathrm{fl}}$ heterozygous mice were crossed with a germline Cre deleter mouse strain to remove the floxed exon 5 . The resulting genotype lacking exon 5 in one allele is denoted Secisbp $2^{+1 \Delta 5}$

N/A, not applicable; Secisbp2, selenocysteine insertion sequencebinding protein 2 .

\section{Conditional inactivation of Secisbp2 in liver}

Embryonic lethality of the knockout mice required the study of selenoprotein biosynthesis in conditional Secisbp2 mice. Germline expression of FLP recombinase removed the gene-trap cassette leaving a conditional (floxed) exon 5 (Fig. $2 \mathrm{~A})$. Sequencing of the mutant transcript confirmed that removal of exon 5 causes a frameshift resulting in a premature stop codon in exon 6 (not shown). Homozygous germline deletion of floxed exon 5 in Secisbp $2\left(\right.$ Secisbp $2^{\Delta 5 / \Delta 5}$ ) yielded the same embryonic lethal phenotype as the knockout-first allele indicating that the Secisbp $2^{\Delta 5}$ allele is not functional (Table 1). We then targeted hepatocytes using a Cre transgene under control of the albumin promoter (Alb-Cre), which we had previously used to inactivate $\mathrm{tRNA}^{[\mathrm{Ser}] \mathrm{Sec}}$ (gene symbol: Trsp) in hepatocytes. The liver is a good model for the study of selenoprotein expression, since targeted ablation of selenoprotein biosynthesis using the conditional Trsp in our hands does not lead to liver failure or other diseases (43, $46,52)$. To test whether liver damage occurs upon Secisbp 2 deletion in hepatocytes, we determined liver transaminase activities in serum. No significant changes according to genotype of the animals were noted ( $n=6-9$; alanine-aminotransferase (ALAT, GPT) activity in $\mathrm{U} / \mathrm{ml} \pm$ standard error of the mean (S.E.M.): controls $0.23 \pm 0.09$ versus mutants $0.24 \pm 0.12$; aspartate-aminotransferase (ASAT, GOT) activity in $\mathrm{U} / \mathrm{ml}$ : controls $0.36 \pm 0.09$ versus mutants $0.43 \pm 0.13$ ) indicating that no apparent liver damage occurred in Alb-Cre; Secisbp $2^{f l / f l}$ mice. Furthermore, the liver not only expresses many selenoproteins that can be measured reliably, but also provides sufficient material to do so.

Western blot analysis of control mouse liver extracts using an antibody directed against the C-terminus of Secisbp2 revealed a prominent band of $120 \mathrm{kDa}$ that represents the full-
A Secisbp $2^{f l}$
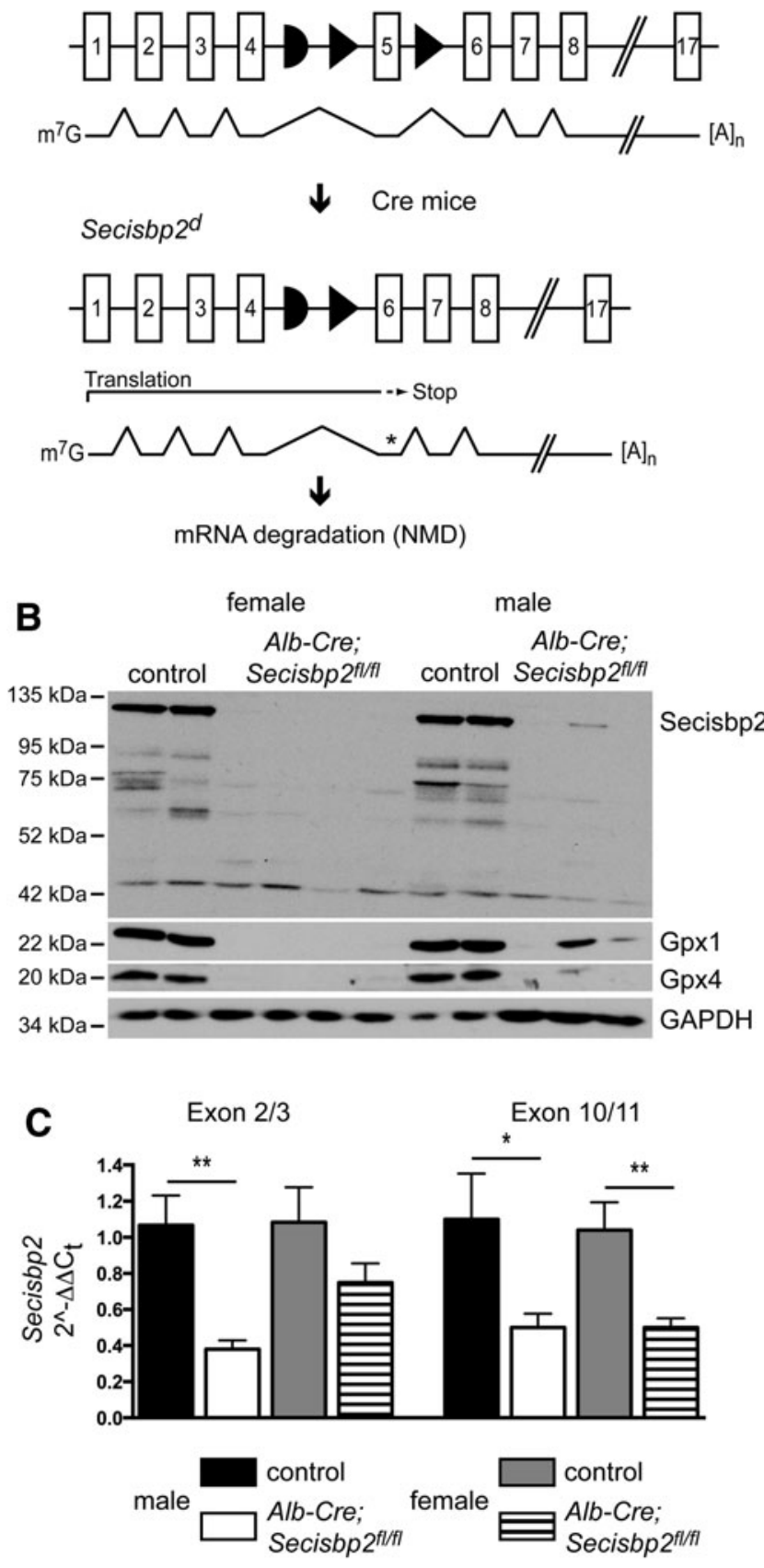

FIG. 2. Conditional inactivation of Secisbp2 in hepatocytes. (A) Cre-mediated recombination removed exon 5 of Secisbp2 generating a frameshift and premature stop (asterisk) in exon 6. (B) Hepatocyte-specific Secisbp2 inactivation substantially reduced Secisbp2, Gpx1, and Gpx4 protein as assessed by western blotting. Forty-five micrograms (Secisbp2) or $25 \mu \mathrm{g}(\mathrm{Gpx} 1, \mathrm{Gpx} 4, \mathrm{GAPDH})$ protein of liver extract was loaded per lane from 2-4 individual mice. An antibody directed against the C-terminus detected full-length Secisbp 2 at $120 \mathrm{kDa}$. GAPDH served as loading control. (C) Secisbp 2 mRNA levels were reduced after removal of exon 5. Quantitative polymerase chain reaction (qPCR) targeting exons $2 / 3$ and exons 10/11 showed that transcript levels are reduced $(* p<0.05$; $* * p<0.01$; Student's $t$-test. $n=6$ ). 
length protein (Fig. 2B, lanes 1, 2, 7, 8). We also observed several minor bands ranging in size from 60 to $90 \mathrm{kDa}$, which presumably represent degradation products generated during tissue workup, since they varied in pattern and intensity depending on the extraction method. The Secisbp2 protein is quantitatively removed from the livers of Alb-Cre; Secisbp $2^{f l f l}$ female and male mice (Fig. 2B; lanes 3-6 and 9-11, respectively). Selenoproteins, Gpx1 and Gpx4, were significantly reduced in the Secisbp2-deficient liver samples confirming the dependence of selenoprotein expression on Secisbp2. In only one male mouse, incomplete recombination occurred leaving residual Secisbp2 protein, which accordingly supported partial Gpx1 and Gpx4 expression (Fig. 2B, lane 10). This shows that all phenotypes observed are caused by Secisbp 2 inactivation and do not depend on another trait genetically coupled to the transgene. The mouse in which the Cre transgene was apparently nonfunctional was omitted from subsequent analyses except Figure 5C. Quantitative polymerase chain reaction (qPCR) using primers specific for exons $2 / 3$ and exons 10/11 revealed a reduction of Secisbp 2 mRNA levels (Fig. 2C). The mutant transcript perhaps is degraded due to the premature stop codon in exon 6. Some of the remaining amounts of $\mathrm{Se}$ cisbp 2 mRNA and protein may arise from endothelial cells and Kupffer cells that are not targeted by Alb-Cre.

\section{Impact of Secisbp2 inactivation on selenoprotein mRNA levels}

Selenoproteins carry in-frame UGA codons in their mRNAs, which could lead to the transcripts being degraded by nonsense-mediated decay (NMD) when Sec incorporation is impaired. Both Se deficiency and hepatic Trsp deficiency impair selenoprotein biosynthesis and thus reduce the amounts of several selenoprotein mRNAs in mouse livers $(13,53)$. We therefore tested whether selenoprotein mRNA levels were also impacted in Alb-Cre; Secisbp $2^{f / f t}$ livers (Fig. 3). We were able to group selenoprotein transcripts into four categories according to their response to Secisbp2 inactivation. Selenoproteins that carry the UGA codon in an upstream exon are in the first group, which potentially fall subject to NMD. Accordingly, many prototypic selenoprotein mRNAs (e.g., Gpxl, Diol) were significantly reduced in mutant livers (Fig. 3A). The second group comprises selenoprotein mRNAs that also carry the UGA codon in an upstream exon, but in contrast to the first group, the reduction of mRNA is smaller and mostly limited to the male liver (Fig. 3B). In the third group are selenoprotein mRNAs carrying the UGA codon in the last exon. These transcripts are generally not subject to NMD and comprise prototypic examples like Txnrd1 (Fig. 3C). One notable exception, Seps mRNA, falls into the fourth group. This mRNA was reduced in male and female Secisbp 2 mutant livers, despite its UGA being located close to the C-terminus in the last exon (Fig. 3D). Accordingly, a clear reduction of Seps protein levels in response to Secisbp 2 mutation was apparent (Fig. 4). In contrast, Sepk was expressed at normal levels. Interestingly, in liver homogenate from mice with $\mathrm{tRNA}^{[\mathrm{Ser}] \mathrm{Sec}}$ inactivation, we found undetectable Sepk levels. This finding suggests that lack of Secisbp 2 may be mechanistically different from a mere blockade of selenoprotein mRNA translation.

SECIS elements are classified as being type 1 or type 2, which contain either an apical loop or an apical bulge. The differential response of selenoprotein mRNAs did not correlate with the type of SECIS element (Table 2). There was also no correlation between the loss of a particular selenoprotein mRNA and its predicted ability to serve as a substrate for NMD. The current rule for NMD requires that the premature stop codon is more than 50 nucleotides upstream of an exon-exon junction. As shown in Table 2, Sps2 and Seps mRNAs were reduced in spite of the fact that these transcripts have only one exon or contain the UGA in the last exon, respectively. Likewise, several selenoprotein mRNAs are reduced even though the UGA codon is too close to the next downstream exon (e.g., Sepp, Sepw, Sepr, Sep15, and Sepm). Interestingly, all of the selenoprotein mRNAs that are not affected by Secisbp2 deficiency (e.g., Txnrd1, Sepi, Sepk, and Sepo) do not follow the rules for NMD (Table 2). Unexpectedly, several selenoprotein mRNAs that showed a reduction in response to Secisbp2 inactivation were not decreased in the livers of Trsp-deficient or Se-deficient male mice, specifically Dio1, Sps2, Gpx4, Sepr, Sep15, and Seps $(11,53)$, although Diol mRNA was significantly reduced in another study (52). Thus, with respect to hepatic selenoprotein mRNA levels, Trsp deficiency and selenium deficiency more closely mimic each other, whereas Secisbp 2 deficiency gives a distinctively different profile.

\section{Impact of Secisbp2 inactivation on hepatic selenoprotein expression}

Sepp is a plasma Se transport protein primarily secreted from the liver by hepatocytes $(12,25,36,41,43)$. In serum, significant Sepp remained in Alb-Cre; Secisbp $2^{f / f l}$ mice compared with controls (Fig. 5A), which corresponded to about $30 \%$ serum Se remaining in the mutants (Fig. 5B). This is two times higher than in Alb-Cre; Trsp $p^{f l / t}$ mice as reported previously (43). In comparison, serum Se in Alb-Cre; Sepp ${ }^{f l f t}$ mice was reduced to $9 \%(25)$. We then analyzed liver extracts for remaining Sepp biosynthesis by western blot analysis. We found several bands corresponding to the full-length protein at $41 \mathrm{kDa}$ and a series of increasingly glycosylated forms up to the $>55 \mathrm{kDa}$ secreted protein forms. Again, more Sepp proteins are detected in the Alb-Cre; Secisbp $2^{f / f l}$ liver than in Alb-Cre; Trsp $p^{A l f l}$ controls (Fig. 5C). We therefore analyzed again Gpx1 and Gpx4 expression in liver extracts, but this time applied more protein $(100 \mu \mathrm{g}$ per lane). Under these conditions, small amounts of residual Gpx1 and Gpx4 proteins were detectable in the Alb-Cre; Secisbp $2^{f / f t}$ liver, but not in Alb-Cre; Trsp ${ }^{f l / f}$ (Fig. 5C). Interestingly, the Txnrd1 protein, which carries $\mathrm{Sec}$ as the penultimate amino acid, was apparently not reduced (Fig. 5C). However, SDS-PAGE analysis cannot exclude the possibility that a Txnrd1 protein lacking the last two amino acids was synthesized due to premature termination at the UGA/Sec codon.

Activity assays are superior to western blots for determination of selenoenzymes, because activity usually critically depends on Sec incorporation. The cellular Gpx activity was reduced by $85 \%$ and $90 \%$ in male and female Alb-Cre; Secisbp $2^{f / / l}$ livers, respectively (Fig. 5D). The cytoplasmic Txnrd activity as measured with the 5,5'-Dithiobis(2-nitrobenzoic acid) (DTNB) assay was significantly reduced in the Alb-Cre; Secisbp $2^{f l / f}$ liver (about $50 \%$ not shown) nicely corresponding to our findings in the Alb-Cre; Trsp ${ }^{\text {fl/A }}$ liver (52). The insulin-based Txnrd assay is considered more 


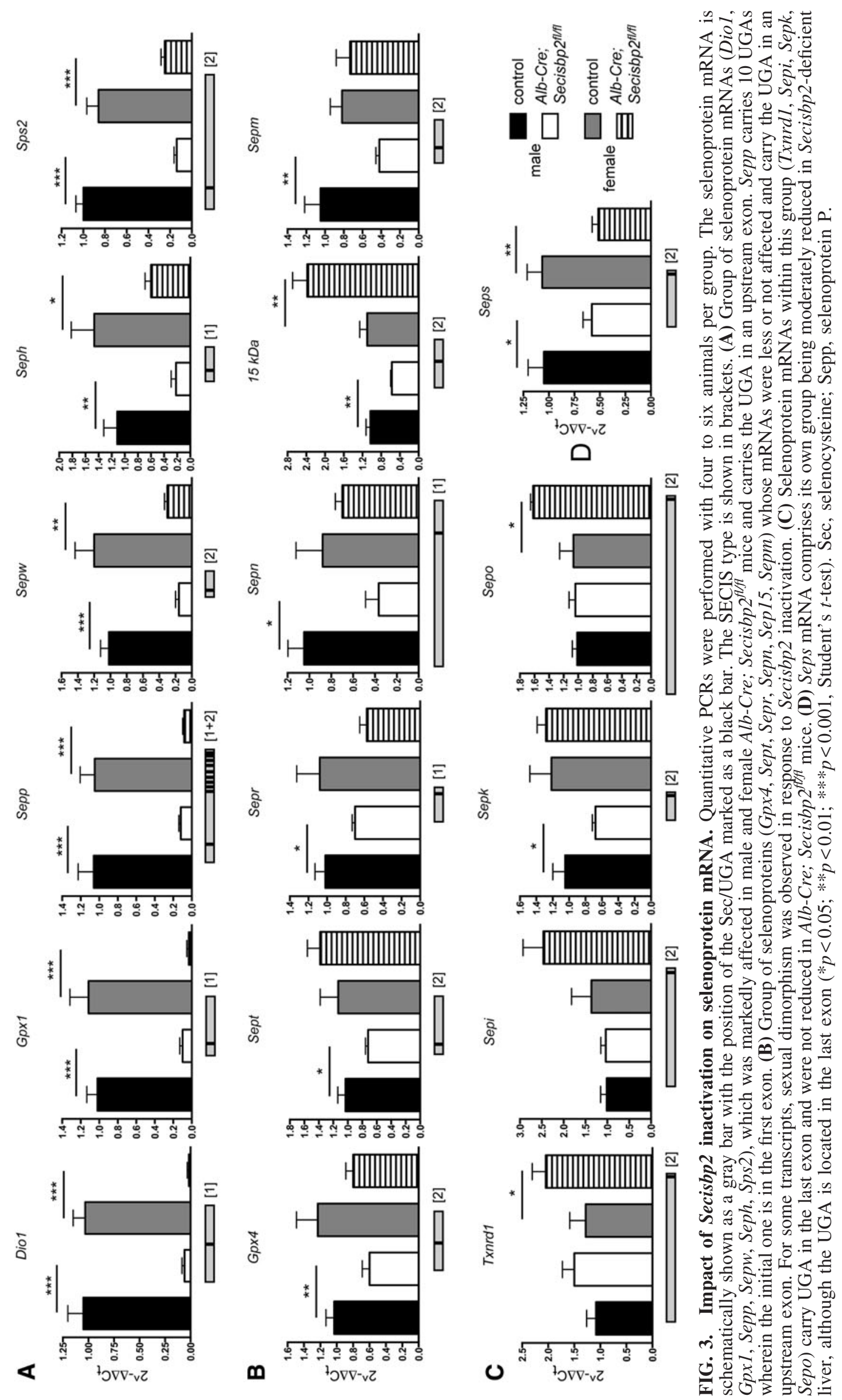


FIG. 4. Impact of Secisbp2 inactivation on Seps and Sepk expression in liver. Seps was significantly reduced in $\mathrm{Alb}-\mathrm{Cre}$; $\mathrm{Se}$ -

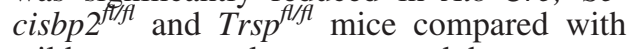
wild-type controls as assessed by western blotting. Sepk expression was similar in control and in Alb-Cre; Secisbp $2^{f / / t}$ mice. In contrast, Sepk was not detectable in the AlbCre; Trsp ${ }^{f f t}$ liver. Forty-five micrograms of total protein extracts was loaded per lane. Tubulin was used as loading control. Representative image of two experiments.

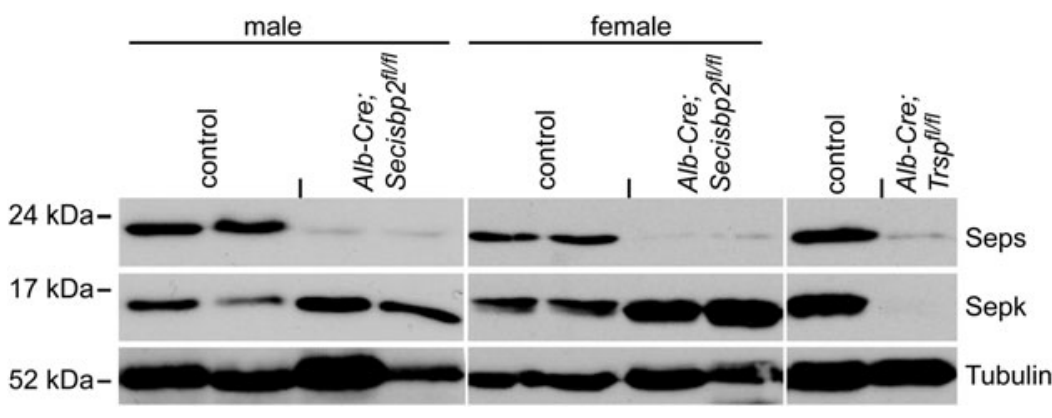

sensitive to the presence of the penultimate Sec residue. Employing this assay, we found an even larger reduction in the Secisbp 2 mutants to about $40 \%$ of control activity (Fig. 5E).

Since the liver is not only composed of hepatocytes, our analysis may be complicated by proteins from endothelial cells and Kupffer cells. We therefore measured the activity of type I deiodinase (Dio1), which is specific for hepatocytes. Whereas Diol mRNA was significantly reduced in the AlbCre; Secisbp $2^{f / f A}$ liver (Fig. 3A), it was obvious that a small fraction of Dio1 activity remained in the Secisbp2-targeted liver (Fig. 5F).

\section{Selenoprotein expression in primary hepatocytes}

To investigate the possibility further that hepatocytes lacking Secisbp 2 can still express small amounts of selenoproteins, we isolated primary hepatocytes from Alb-Cre; Secisbp $2^{f / f}$ mice and litter mate controls thus removing background signals derived from endothelium or Kupffer

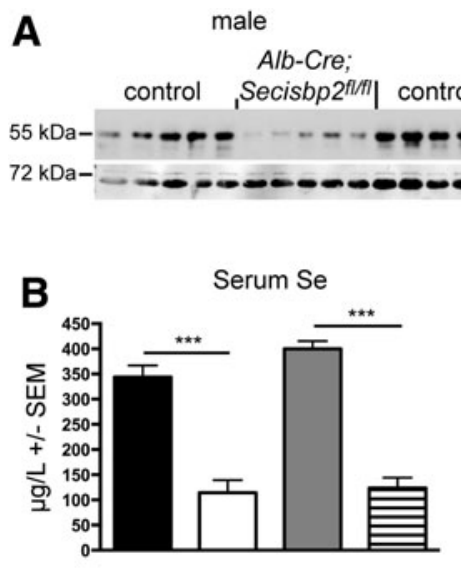

female Alb-Cre; ecisbp2 2 fIT
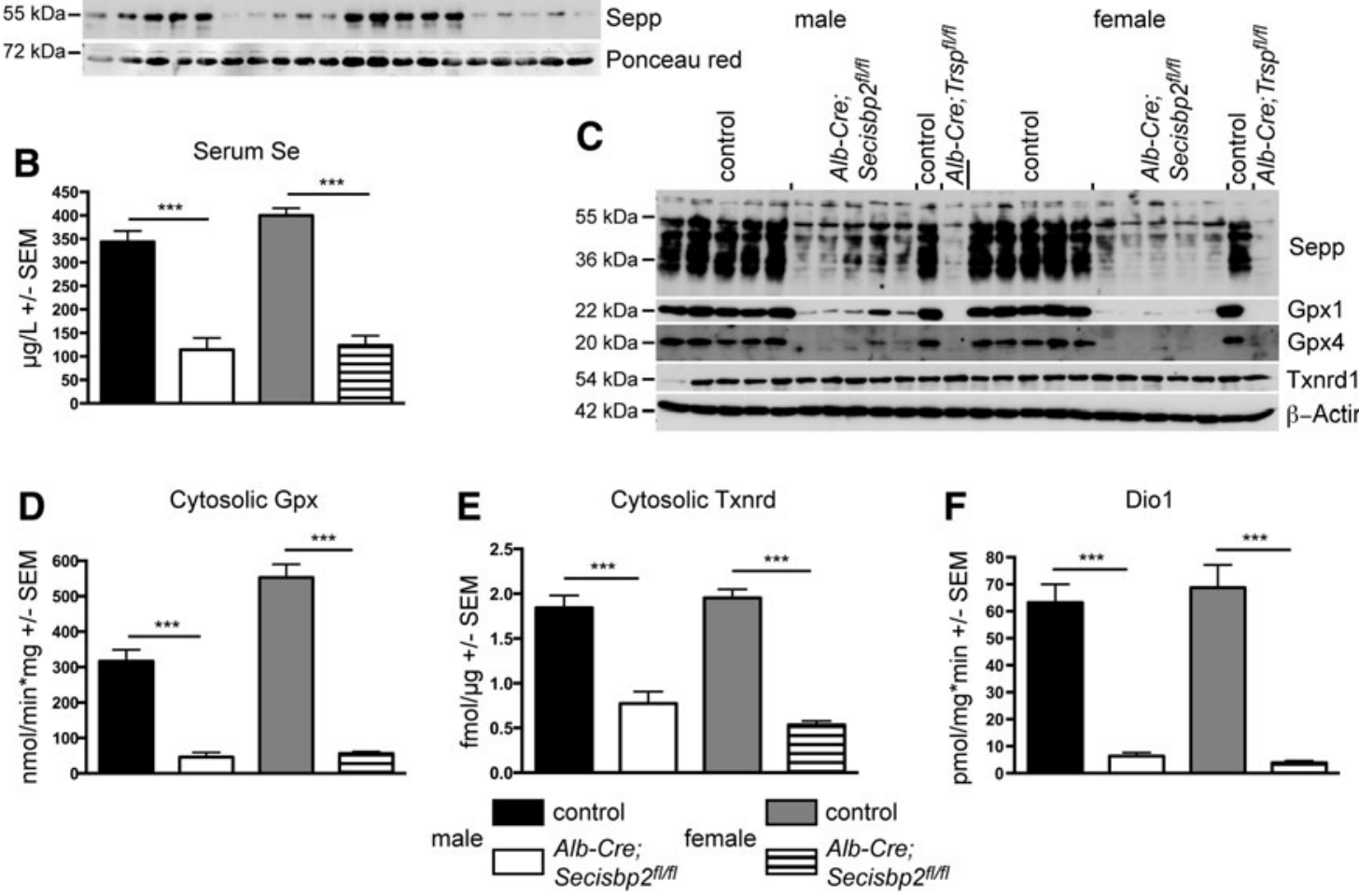

FIG. 5. Impact of Secisbp2 inactivation on hepatic selenoprotein expression. (A) Sepp expression in serum was significantly decreased in Alb-Cre; Secisbp $2^{f l f l}$ mice compared with controls as assessed by western blotting. (B) The Se content in serum was reduced in mutated mice. (C) Western blot analysis of selenoprotein expression in liver. Significant Sepp remained in Alb-Cre; Secisbp $2^{f / f l}$ mice compared with the wild-type controls. Bands of different sizes represent the full-length peptide $(41 \mathrm{kDa})$ and increasing glycosylated forms. More Sepp protein of all sizes was detected in Alb-Cre; Secisbp $2^{f / f}$ than in Alb-Cre; Trsp ${ }^{f l f l}$ liver. For Gpx1 and Gpx4, small amounts of residual protein could be detected in the mutant mice. One hundred micrograms of protein from individual mice was applied per lane. (D) Activity of cytosolic Gpx was significantly decreased in Alb-Cre; Secisbp $2^{f / f l}$ mice (by $85 \%$ and $90 \%$ in males and females, respectively). (E) Cytosolic Txnrd1 activity was significantly reduced, although the protein level was not reduced. (F) Dio1 activity was markedly reduced. For Se content in serum and enzyme activity assays, five to six animals per group were analyzed $(* * * p<0.001$ Student's $t$-test). 
Table 2. mRna Features of Selenoprotein Classes Differentially Affected by Secisbp2 Mutations

\begin{tabular}{|c|c|c|c|c|}
\hline $\begin{array}{l}m R N A \text { response to hepatic } \\
\text { Secisbp } 2 \text { deficiency }\end{array}$ & Gene & $\begin{array}{l}\text { Type of } \\
\text { SECIS }\end{array}$ & $\begin{array}{c}\text { Follows rules for } \\
\text { NMD (UGA>50 nt } \\
\text { upstream of } \\
\text { exon/exon junction) }\end{array}$ & $\begin{array}{c}\text { mRNA response } \\
\text { to hepatic } \\
\text { Trsp deficiency } \\
\text { in males }\end{array}$ \\
\hline \multirow[t]{6}{*}{ Greatly reduced in males and females } & Diol & 1 & Yes & Reduced \\
\hline & Gpxl & 1 & Yes & Reduced \\
\hline & Sepp & 1 and 2 & No (distance is $26 \mathrm{nt}$ ) & Reduced \\
\hline & Sepw & 2 & No (distance is $15 \mathrm{nt}$ ) & Reduced \\
\hline & Seph & 2 & Yes & Not tested \\
\hline & Sps 2 & 2 & No (only one exon) & No change \\
\hline \multirow[t]{6}{*}{ Modestly reduced in males only } & $G p x 4$ & 2 & Yes & No change \\
\hline & Sept & 2 & Yes & Reduced \\
\hline & Sepr & 1 & No (distance is $34 \mathrm{nt}$ ) & No change \\
\hline & Sepn & 1 & Yes & Not tested \\
\hline & $15 \mathrm{kDa}$ & 2 & No (distance is $28 \mathrm{nt}$ ) & No change \\
\hline & Sepm & 2 & No (distance is $21 \mathrm{nt}$ ) & Not tested \\
\hline Modestly reduced in males and females & Seps & 2 & No (UGA in last exon) & No change \\
\hline \multirow[t]{4}{*}{ Not reduced in males and females } & Txnrd1 & 2 & No (UGA in last exon) & No change \\
\hline & Sepi & 2 & No (UGA in last exon) & Not tested \\
\hline & Sepk & 2 & No (distance is $5 \mathrm{nt}$ ) & Reduced \\
\hline & Sepo & 2 & No (UGA in last exon) & Not tested \\
\hline
\end{tabular}

${ }^{\mathrm{a}}$ Based on (11) and (12) in which only male mice were analyzed.

NMD, nonsense-mediated decay; nt, nucleotides.

cells. In parallel, we isolated hepatocytes from Alb-Cre; $\operatorname{Trsp}{ }^{f l f l}$ mice. Comparing Secisbp2-deficient hepatocytes with Trsp-deficient cells, in the same analyses, allows one to separate effects simply related to impaired selenoprotein mRNA translation from effects specific for Secisbp2 inactivation. Messenger RNA levels for Secisbp 2 were only reduced in Alb-Cre; Secisbp $2^{f l / f l}$ cells, but not in Trsp-deficient hepatocytes, consistent with the premature termination codon in exon 6 of the Secisbp 2 mutant (Fig. 6A). Gpx1 mRNA levels were almost undetectable in both Secisbp2 and Trsp mutant hepatocytes, consistent with its established sensitivity to NMD (Fig. 6B). Gpx4 was reduced in both mutants, but more pronounced in the Secisbp 2 mutant (Fig. 6C). Txnrd1 was not affected by either gene deletion (Fig. 6D). The hepatocyte-specific mRNA for Sepp was reduced in both mutants, but again more severely affected in Secisbp2-deleted cells (Fig. 6E). As in whole liver extracts, we observed Sepp biosynthesis in Secisbp2-deleted cells at a low level, this time however, definitely derived from hepatocytes (Fig. 6G). At close inspection, the Sepp species with the highest molecular weight are not visible in Trsp mutant cells, but it is expressed in Secisbp 2 mutant cells (arrow). Low residual expression of Gpx4 was not observed, possibly because of its much lower expression level than Sepp. A remarkable finding was the detection of low Dio1 activity in Secisbp2-deleted cells, but none in Trsp mutant cells (Fig. 6H). This was in stark contrast to higher Diol mRNA in Trsp mutants than in Secisbp2 mutants (Fig. 6F). This circumstantial evidence suggests that a very low level of translation of at least some selenoprotein mRNAs may occur in the absence of Secisbp2.

\section{Expression of other known SECIS-binding proteins}

Given the possible persistence of an inefficient mechanism of selenoprotein expression in hepatocytes, we speculated that one of the other SECIS-binding proteins may potentially compensate for the loss of Secisbp2 in hepatocytes. Alter- natively, their expression levels may change when Secisbp 2 or selenoprotein transcript levels are reduced. We therefore investigated whether Secisbp2 gene targeting changed mRNA expression of any of the other SECIS-binding proteins. Based on qPCR, neither nucleolin (Fig. 7A), Ybxl (Fig. 7B), Rpl30 (Fig. 7C), or Secisbp2l (Fig. 7D) mRNAs were significantly changed in the livers of male Alb-Cre; $\mathrm{Se}$ $\operatorname{cisbp} 2^{\mathrm{fl} / \mathrm{fl}}$ mice, although a significant increase in nucleolin mRNA was noted in female mutants (Fig. 7A). The transcript encoding the inhibitory SECIS-binding protein, eIF4a3, which represses Gpx1 mRNA translation in Se deficiency (9), did not change (Fig. 7E). Based on western blotting, the protein levels of L30, nucleolin, and eIF4a3 were not significantly different between the control and Alb-Cre; $\mathrm{Se}$ $\operatorname{cisbp} 2^{\mathrm{fl} / \mathrm{fl}}$ female mice (Fig. 7F; Supplementary Fig. S2).

\section{Induction of Nrf2 target genes in livers of Secisbp2 mutant mice}

In Alb-Cre; $\operatorname{Trsp}{ }^{\mathrm{fl} / \mathrm{fl}}$ mice, which are globally defective in hepatic selenoprotein expression, nuclear factor, erythroid-derived, like 2 (Nrf2)-dependent gene expression was induced in response to the lack of antioxidant selenoproteins (46). We therefore tested mRNA expression of Nrf2-dependent genes, Nqo1, Cd36, Hmox1, Gstm1, Gstm3, Gstal, and Gsta4. As expected, we found several-fold induction of most tested genes in male and female mutant mice (Fig. 8A). Interestingly, female Alb-Cre; Secisbp $2^{\mathrm{fl} /}$ ${ }^{\mathrm{fl}}$ mice showed higher induction in more genes than males. Staining for proteins modified by the Nrf2-inducing mediator 4hydroxynonenal (4-HNE) by western blotting did not reveal increased signals in the Secisbp2 mutant liver suggesting efficient detoxification by Nrf2 pathway genes (Fig. 8B).

\section{Discussion}

Previous studies in vitro and in cell culture suggested that Secisbp 2 is essential for translation of selenoprotein mRNAs 

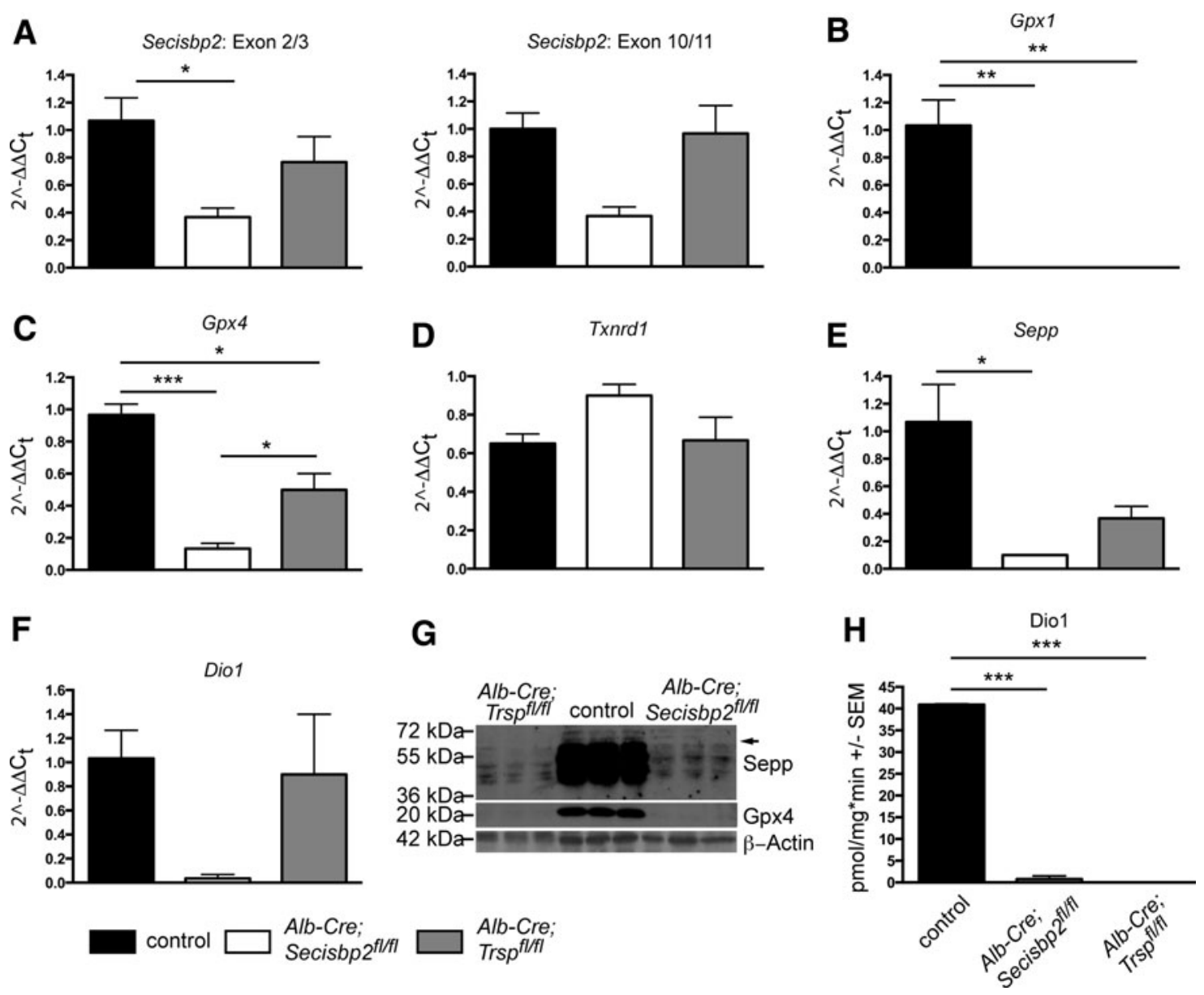

FIG. 6. Selenoprotein expression in primary hepatocytes. (A) Secisbp 2 mRNA levels were reduced in Alb-Cre; Secisbp $2^{f l / f l}$ hepatocytes, but not in Alb-Cre; Trsp ${ }^{y / f l}$ cells. (B) Gpxl mRNA was completely lost in both mutant cell types. (C) Gpx4 mRNA levels were more strongly affected in Alb-Cre; Secisbp ${ }^{f l / f l}$ than in Alb-Cre; Trsp ${ }^{f / f l}$ hepatocytes. (D) Txnrdl mRNA was not changed. (E) Sepp mRNA was more affected in Secisbp2-deleted hepatocytes than in Trsp-deleted cells. (F) Only a small amount of Diol mRNA was detected in Alb-Cre; Secisbp $2^{f l f l}$ hepatocytes, whereas Diol mRNA was not significantly reduced in $A l b-C r e ; \operatorname{Trsp}^{f l / f l}$. (G) Western blot analysis of selenoprotein expression. Sepp was present in several forms representing the full-length peptide $(41 \mathrm{kDa})$, partially glycosylated and the fully glycosylated form $(55 \mathrm{kDa}$, arrow). (H) Secisbp2 targeting reduced Dio1 activity in primary hepatocytes more than 90\%, but targeting of Trsp was even more effective despite higher mRNA levels $(* p<0.05$; ** $p<0.01$; *** $p<0.001$; one-way ANOVA with the Bonferroni's post hoc test).

(17). Our novel mouse mutants now permit us to investigate Secisbp2 function in embryonic development and in any specific cell type in vivo at any chosen developmental time point, provided a suitable Cre driver is chosen. In summary, our data support that Secisbp 2 is required for efficient selenoprotein expression and that it may play a role both in mRNA translation and mRNA stability. Comparison with mice lacking RRNA $^{[\mathrm{Ser}] \mathrm{Sec}}$ revealed residual selenoprotein expression and a less severe phenotype in Secisbp2-deficient mice, suggesting the existence of a compensatory or Secisbp2-independent molecular mechanism, which needs to be elucidated in future studies.

We chose hepatocytes as a model system, because, unlike mouse embryonic fibroblasts $(28,45)$, these cells survive abrogation of selenoprotein biosynthesis (43). A reason for this may be efficient transcriptional induction of Nrf2-responsive antioxidant proteins like glutathione-S-transferases (GST) (46). Hepatocytes allowed us to investigate a large number of selenoproteins at the level of protein expression or enzyme activity. We further took advantage of a conditional Trsp allele and compared the effects of Secisbp2 inactivation with $\mathrm{tRNA}^{[\mathrm{Ser}] \mathrm{Sec}}$ inactivation. Throughout, we observed a low level of selenoprotein expression remaining after $\mathrm{Se}$ cisbp2 inactivation. Similarly, quantification of Nrf2dependent Gst mRNAs revealed significant induction of these genes in the Secisbp 2 mutant liver, but much lower than in mice harboring a conditional deletion of Trsp (46). For example, we found a 1.3-fold induction (normalized to $18 \mathrm{~S}$ rRNA) of Gstml in our male mutants compared with 3.2-fold in Trsp mutants [normalized to Gusb mRNA in (45)]. Likewise, Gstal is induced 3.2-fold in male Secisbp2 mutants compared with 23.4-fold in Trsp mutants. Except for one male (Fig. 2B, lane 10), incomplete gene inactivation is not a likely reason for the milder effect, since we used the same Alb-Cre driver for both Secisbp 2 and Trsp. Cre expression starts during embryonic stages, and the animals were analyzed at postnatal day 35 allowing ample time for Secisbp2 recombination, Secisbp2 protein turnover, and loss of 

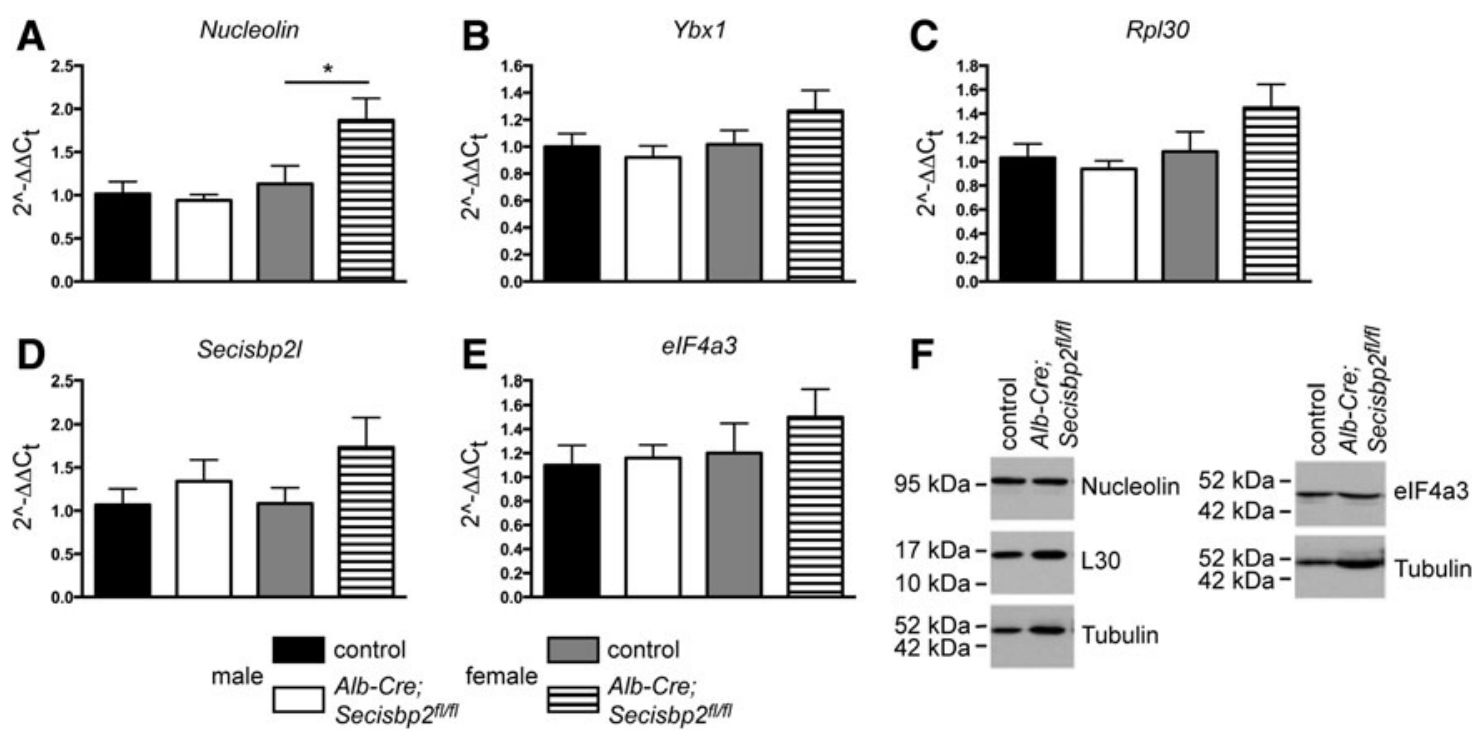

FIG. 7. Analysis of other SECIS-binding proteins. (A-E) Transcript levels of alternative SECIS-binding proteins were analyzed. None was significantly affected in livers of Alb-Cre; Secisbp $2^{f l f l}$ mice compared with the wild-type controls. One exception: in females, nucleolin mRNA is slightly increased, five to six animals per group (*p<0.05; Student's $t$-test). (F) Representative western blots for L30 $(10 \mu \mathrm{g})$, nucleolin $(10 \mu \mathrm{g})$, and eIF4a3 (60 $\mu \mathrm{g}$ per lane). The expression levels of these proteins were not significantly different between control and Alb-Cre; Secisbp $2^{f / f t}$ mice based on two independent analyses $(n=3$ in each group; Supplementary Fig. S2).

Secisbp2-dependent selenoproteins. Cell types not targeted by $\mathrm{Alb}$-Cre-like endothelial cells or Kupffer cells may account for a minor fraction of selenoprotein expression, but should contribute the same background in both Secisbp 2 and Trsp mutant liver. Finally, within the liver, Dio1 and Sepp are selenoproteins specific for hepatocytes and residual expression of these proteins thus cannot stem from other cell types. This interpretation is supported by our hepatocyte culture experiments, in which Secisbp2- and Trsp-deficient cells were analyzed in parallel. Again, both the Dio1 activity and Sepp expression were higher in cells lacking Secisbp 2 than in cells lacking Trsp. Compared with Trsp mutants, a higher Diol activity in Secisbp2-deficient hepatocytes was found despite lower Diol mRNA levels. Whereas these considerations are limited by measurements close to the detection limits of the methods, a comparison of embryonic development lends further support to the notion that Secisbp 2 inactivation is less detrimental than Trsp inactivation, that is, Secisbp $2^{-/-}$embryos fail before gastrulation (clearly after implantation), while $\operatorname{Tr} s p^{-/-}$embryos fail before implantation (6). This is consistent with the phenotypes of embryos lacking single essential selenoproteins. Gpx $4^{-1-}$ embryos die before E7.5 $(27,45,59)$. Txnrd1 ${ }^{-1-}$ embryos die around E10.5 (5, 28). Developmental failure of Secisbp2 $2^{-/-}$embryos precedes failure in mice lacking glutathione biosynthesis $\left(G c l c^{-/-}\right)$, which do not develop mesoderm during gastrulation (49).

What could be the mechanism involved in the maintenance of a minor fraction of selenoprotein expression? One possibility is the low level expression of a truncated, hypomorphic Secisbp 2 protein that initiates from Met302 in exon 6 after the Cre-induced frameshift. It is, however, inherently difficult to exclude the existence of a molecule that remained below the detection limit of our western blot. A second potential mechanism for functional compensation of Secisbp2 inactivation may be the activity of another SECIS-binding protein. The expression of other SECIS-binding proteins does not change at the protein level, although nucleolin mRNA levels were increased in female mutant mice. More importantly, none of the known SECIS-binding proteins have been shown to substitute for Secisbp2 in Sec incorporation, including SECISBP2L (19).

A third possibility is incorporation of another amino acid in place of Sec, ultimately a mechanism of nonsense suppression. Examples of nonsense suppression are already known with regard to selenoproteins. For example, the aminoglycoside G418 can stimulate the incorporation of Arg by a near cognate tRNA into Gpx1 (23). Dietary Se deficiency results in incorporation of Cys at the penultimate UGA codon of Txnrd1 leading to a variant with about $10 \%$ activity compared with the Sec-containing enzyme $(32,58)$. All these mechanisms of nonsense suppression would ultimately lead to full-length, but inactive or minimally active, selenoenzymes. In the case of Txnrd, a significant activity is preserved in male and female Secisbp 2 mutants with $41 \%$ and $27 \%$ of wild-type activity, respectively. Considering that the amount of Txnrd1 mRNA is not reduced, a fourth, although hypothetical, possibility arises: a low-efficiency pathway of Sec incorporation that is independent of Secisbp2 analogous to pyrrolysine insertion (51). It will require future studies in carefully designed systems to uncover such a mechanism.

Finally, an intriguing novel finding of our study is the major role that Secisbp2 plays in selenoprotein mRNA abundance. We did not expect such a massive reduction of selenoprotein mRNAs in the absence of Secisbp2. Clearly, it was expected that failure to translate selenoprotein mRNAs may subject these transcripts to NMD, although to date, only the Gpx1 mRNA has been shown to undergo NMD (35). Our experiments revealed that various selenoprotein mRNAs react differentially to the absence of Secisbp2. Moreover, direct 
A
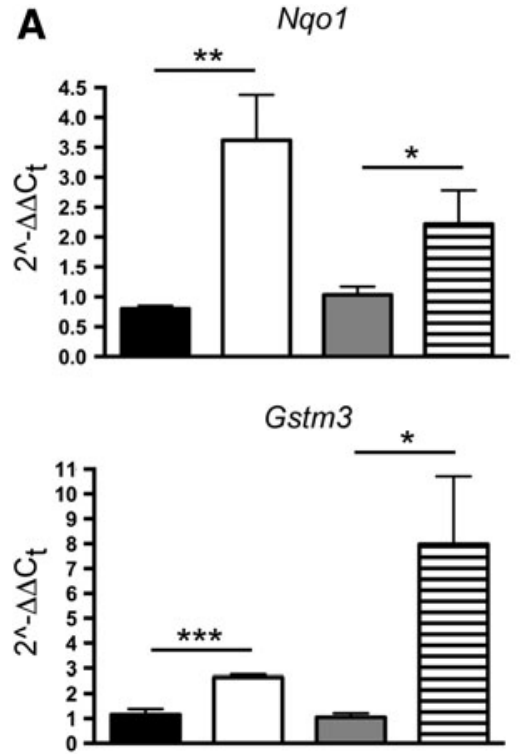

Cd36

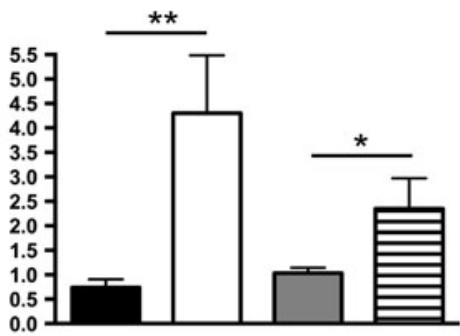

Gsta1

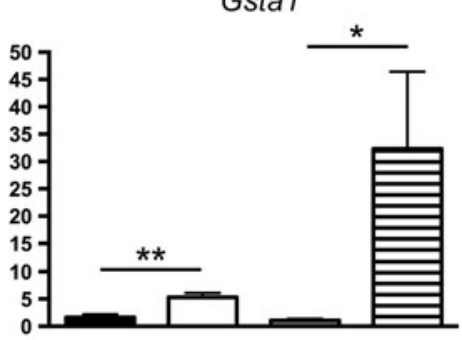

B

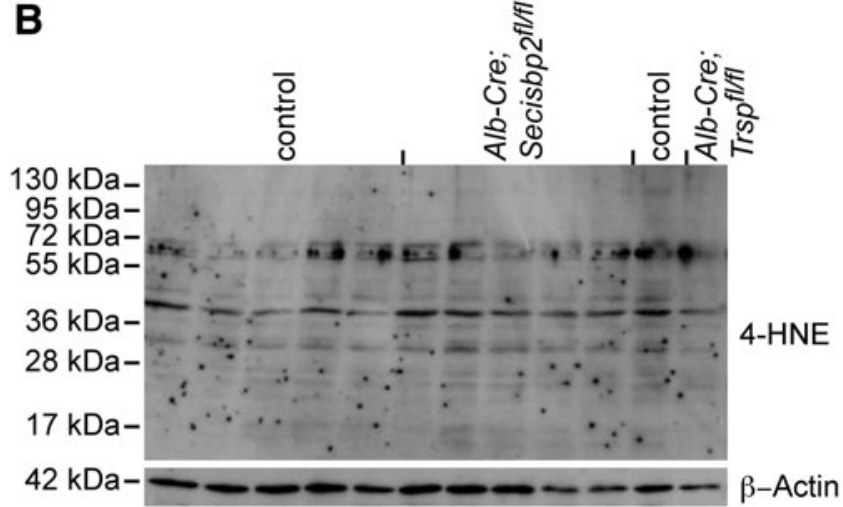

Gstm1

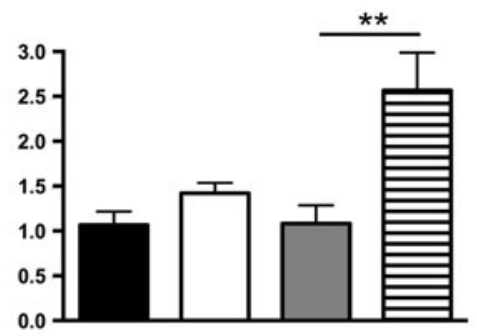

Gsta4
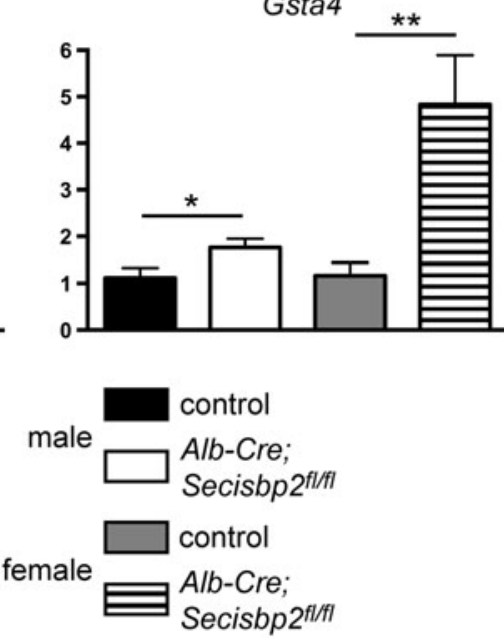

FIG. 8. Induction of Nrf2-dependent gene expression in liver. (A) Transcript levels of several Nrf2 target genes were increased in livers of Alb-Cre; Secisbp $2^{f / f f}$ mice compared with wild-type controls. 18S-rRNA served as the reference gene. (B) Western blot analysis for 4-HNE revealed no differences between Secisbp2-depleted livers and controls $(* p<0.05$; $*^{*} p<0.01 ; * * * p<0.001$; Student's $t$-test). 4-HNE, 4-hydroxy nonenal; Nrf2, nuclear factor, erythroid derived, like 2.

comparison with cells deficient for tRNA ${ }^{[\mathrm{Ser}] \mathrm{Sec}}$ or cells lacking adequate Se demonstrates that lack of translation and subsequent NMD alone cannot account for reduced selenoprotein mRNA levels. Furthermore, several transcripts that showed a decrease in Secisbp2 deficiency do not follow the canonical rules for NMD (Table 2). Interestingly, some mRNAs were more strongly reduced upon Secisbp2 inactivation than upon Trsp inactivation. Whereas not explored in detail here, these findings point to a potential role of Secisbp2 in the stabilization of a subset of selenoprotein mRNAs in vivo. A previous study showed that stable knockdown of SECISBP2 in a malignant mesothelioma cell line reduced the levels of a different group of selenoprotein mRNAs (50). The differences between the two studies may be due to the cell type, in vitro versus in vivo, or knockdown versus Secisbp 2 inactivation.

Differential binding of selenoprotein mRNAs by Secisbp2 has been implicated in establishing the hierarchy among selenoproteins and is sensitive to mutations in the lysine-rich domain of Secisbp2 (8). Patients carrying the R540Q mutation in SECISBP2 exhibit a selective deficiency of selenoprotein expression (20). If patients carry more severe mutations, they suffer from a more global selenoprotein deficiency associated with a more severe clinical syndrome (40). Fibroblasts from these patients show changes of mRNA levels in the same way as in Secisbp2-deficient hepatocytes (40). Nevertheless, phenotypes of patients with mutations in SECISBP2 are still weaker than complete Secisbp2 gene inactivation afforded in our model. This suggests that point mutations observed in patients target specific functions of SECISBP2 or lead to hypomorphic, but not entirely inactive, alleles.

\section{Materials and Methods}

\section{Nomenclature}

Secisbp2 and SECISBP2 refer to rodent and human proteins, respectively. Names in italics indicate the respective genes.

\section{Mouse models}

Transgenic mice harboring the knockout-first allele of Secisbp 2 were obtained from the European Conditional 
Mouse Mutagenesis Consortium (EUCOMM) after the gene was prioritized upon our request. The construct encompasses a FRT-flanked gene-trap cassette in intron 4 leading to an inframe protein fusion with exon 4 followed by polyadenylation (Secisbp2 ${ }^{\text {tm1a(EUCOMM)Wtsi }}$ ). The gene-trap cassette was removed by intercross with a germline deleter FLPe transgenic mouse resulting in a conditional allele with exon 5 flanked by $\operatorname{lox} P$ elements $\left(\operatorname{Secisbp} 2^{f l}\right)$. Deletion of conditional exon 5 in the germline using a deleter Cre transgenic mouse strain resulted in a Secisbp $2^{\Delta 5}$ allele, a functional knockout. The breeding colony was maintained on breeding diets (Ssniff, Soest, Germany) containing on average 0.2$0.3 \mathrm{ppm}$ Se. Upon weaning, animals that were to be examined by western blotting and used for serum Se analysis were maintained on a low Se diet (Altromin, Lage, Germany; diet C1045 containing $0.08 \mathrm{ppm}$ Se) supplemented with selenite to an adequate $\mathrm{Se}$ concentration $(0.15 \mathrm{ppm} \mathrm{Se}$, a dose defined as the recommended dietary allowance for mice, designated RDA) as in earlier experiments (36). The Se content of the diets used in the experiments were determined by total reflection X-ray fluorescence (TXRF) analysis that verified the intended Se content. Animal experiments were approved by the local governmental authorities (Landesamt für Gesundheit und Soziales, LAGeSo Berlin, Germany). Genotyping was done by PCR using primers Secisbp2-wt(fwd): GGTTCTGAGTTCCACTTAAAG, Secisbp2-rev2: GGTAT GCAAGGGCCACCTTTG and Secisbp2-loxP(rev): GGTA TGCAAGGGCCACCTTTG. Alb-Cre and Trsp genotyping was done as described (43). For Secisbp $2^{\Delta 5}$ genotyping, primers Secisbp2-rev2 (described above) and Secisbp2fwd1: TCTGCTTCTGCCTCCTAAATG were used.

\section{Primary hepatocytes}

Primary hepatocytes were isolated as described (55) from female mice. Forty-eight hours after isolation, cells were harvested for analysis.

\section{Hormone measurements}

TSH and total serum $\mathrm{T}_{4}$ and $\mathrm{T}_{3}$ were measured by radioimmunoassays adapted to mice as described before (7).

\section{Selenoenzyme analysis}

Gpx assays were carried out with tert-butyl hydroperoxide and Txnrd activities were assessed with the DTNB assay in tissue homogenates as described (41). The protein concentration was determined by the Bradford method using IgG as a standard. The Diol activity was determined as described with ${ }^{125} \mathrm{I}_{-} \mathrm{rT}_{3}$ as the substrate (52). Fifteen micrograms of membrane fraction protein was used, with $1 \mu M$ unlabeled $\mathrm{rT}_{3}$. The reaction time was $60 \mathrm{~min}$ and the reaction temperature $37^{\circ} \mathrm{C}$. Five to six male and female animals were analyzed for each genotype. The assay was done in triplicate.

\section{Insulin-dependent Txnrd assay}

Since DTNB may be reduced by GSTs (which were found increased in the livers of Secisbp2-deficient mice), the insulin-dependent fluorescent Txnrd assay from IMCO (Stockholm, Sweden) was also used to determine Txnrd activities in $35 \mu \mathrm{g}$ of protein from liver cytosols (26). We followed the manufacturer's recommendations with one minor modifica- tion, that is, the Txnrd standards were adjusted to match the range of our samples (in $\mathrm{n} M$ ): $0.125,0.25,0.375,0.50,0.625$ and results were given in fmol Txnrd per $\mu \mathrm{g}$ cytosolic protein.

\section{Liver transaminase determination}

ALAT and ASAT measurements in serum were performed according to standard coupled tests involving 2-ketoglutarate and NADH plus alanine and lactate dehydrogenase (for ALAT) or aspartate and malate dehydrogenase (for ASAT). The decrease in $A_{340}$ was followed over 3 min and from the slope of the linear part of the curve, the activity was calculated as $1 \mathrm{U}=1 \mu \mathrm{mol} / \mathrm{min}$. The number of animals tested: male controls (6), female controls (9), male mutants (6), and female mutants (9).

\section{Western blot analysis}

An antiserum directed against the C-terminal 349 amino acids of mouse Secisbp2 was generated by the Protein Tech Group, Chicago, IL (used at 1:1000). For Gpx1 (1:10,000; rabbit antiserum from Abcam, Cambridge, United Kingdom), 25-100 $\mu \mathrm{g}$ protein from cytosolic fraction was separated on SDS/12\% polyacrylamide gels. For Gpx4 (1:10,000; rabbit antiserum against amino acids 32-43 of rat protein made by Biosynthesis, Lewisville), $40 \mu \mathrm{g}$ of whole testis homogenate and 25 or $100 \mu \mathrm{g}$ of liver homogenate was used. The antiserum directed toward Sepp (1:400) has been generated in rabbits by immunization with a synthetic C-terminal peptide (ImmunoGlobe, Himmelstadt, Germany), and its specificity was verified using wild-type and Sepp-knockout mice (15, 43). For serum Sepp quantification, $0.2 \mu \mathrm{l}$ serum was applied per lane. For Txnrd1 (1:1000; mouse monoclonal antibody; Abcam), $100 \mu \mathrm{g}$ of protein from cytosolic fraction was used for western blot analysis. Antibodies against Sepk, Seps, eIF4a3, and L30 were from Sigma (Munich, Germany; ATLAS Prestige antibodies, rabbit polyclonal) used at 1:1000, $1: 20,000,1: 1000$, and 1:5000 dilution, respectively. After electrotransfer, nitrocellulose membranes were stained with Ponceau Red, photographed, and blocked with 5\% BSA for $1 \mathrm{~h}$ at $25^{\circ} \mathrm{C}$. As loading controls, the following antibodies were used: rabbit polyclonal $\beta$-actin antiserum (Sigma) at 1:2000 dilution, mouse monoclonal against beta I and II tubulin (Abcam) at 1:100,000, or mouse monoclonal 6C5 against GAPDH (Abcam) at 1:300,000.

\section{Selenium measurements}

Se was determined by TXRF using a Picofox ${ }^{\mathrm{TM}} \mathrm{S} 2$ instrument (Bruker nano, Berlin, Germany) (15). Gallium was used as the internal standard for quantification and reference samples for serum (Sero, Billingstad, Norway) were included in all analyses and results were always within the reference range. All samples were measured in duplicate.

\section{qPCR analysis}

Total RNA was isolated from powdered mouse tissue according to the TRIzol protocol (Invitrogen, Darmstadt, Germany). Samples were treated with RQ1 RNase-Free DNase (Promega, Madison, WI). Total RNA from primary hepatocytes was isolated with the Aurum Total RNA Minikit (Biorad, München, Germany). cDNA was synthesized using the iScript cDNA synthesis kit (Biorad) according to the 
manufacturer's protocol. qPCR was performed using SYBR Green from Abgene (Thermo Scientific, Epsom, United Kingdom) on an iCycler (Biorad). Primers used for qPCR detection of Nrf2 target genes were as described previously (46). Primers specific for selenoproteins and Nrf2 target genes are described in Supplementary Table S1. 18S rRNA was used as reference gene for mRNA quantification.

\section{Statistics}

For all computations, GraphPad Prism software was used for the tests indicated in the figure legends. Data are expressed as mean \pm S.E.M. Statistical significance was determined and indicated as $* p<0.05$, $* * p<0.01$, or $* * * p<0.001$.

\section{Acknowledgments}

The authors thank Antje Kretschmer, Anja Fischbach, Vartitér Seher, and Ursula Reuter for excellent technical assistance. Dr. Markus Schupp, Charité-Universitätsmedizin Berlin helped with primary hepatocyte cultures, Dr. Carmen Birchmeier provided FLPe and Cre deleter mice, Dr. Wolfgang Wurst prioritized Secisbp2 in EUCOMM. The study was funded by Deutsche Forschungsgemeinschaft DFG Schw914/2-1 and GK1208 to the U.S. and National Institutes of Health grants R01DK085391 and R01DK07859 to D.M.D.

\section{Author Disclosure Statement}

All authors stated that no competing financial interests exist.

\section{References}

1. Azevedo MF, Barra GB, Naves LA, Ribeiro Velasco LF, Godoy Garcia CP, de Castro LC, Amato AA, Miniard A, Driscoll D, Schomburg L, and Assis Rocha NF. Selenoprotein-related disease in a young girl caused by nonsense mutations in the SBP2 gene. J Clin Endocrinol Metab 95: 4066-4071, 2010.

2. Baron $\mathrm{C}$, Heider $\mathrm{J}$, and Böck A. Interaction of translation factor SELB with the formate dehydrogenase $\mathrm{H}$ selenopolypeptide mRNA. Proc Natl Acad Sci U S A 90: 41814185, 1993.

3. Berry MJ, Banu L, Chen YY, Mandel SJ, Kieffer JD, Harney JW, and Larsen PR. Recognition of UGA as a selenocysteine codon in type I deiodinase requires sequences in the 3' untranslated region. Nature 353: 273-276, 1991.

4. Bianco AC, Salvatore D, Gereben B, Berry MJ, and Larsen PR. Biochemistry, cellular and molecular biology, and physiological roles of the iodothyronine selenodeiodinases. Endocr Rev 23: 38-89, 2002.

5. Bondareva AA, Capecchi MR, Iverson SV, Li Y, Lopez NI, Lucas O, Merrill GF, Prigge JR, Siders AM, Wakamiya M, Wallin SL, and Schmidt EE. Effects of thioredoxin reductase-1 deletion on embryogenesis and transcriptome. Free Radic Biol Med 43: 911-923, 2007.

6. Bösl MR, Takaku K, Oshima M, Nishimura S, and Taketo MM. Early embryonic lethality caused by targeted disruption of the mouse selenocysteine tRNA gene (Trsp). Proc Natl Acad Sci U S A 94: 5531-5534, 1997.

7. Braun D, Wirth EK, Wohlgemuth F, Reix N, Klein MO, Grüters A, Köhrle J, and Schweizer U. Aminoaciduria, but normal thyroid hormone levels and signalling, in mice lacking the amino acid and thyroid hormone transporter Slc7a8. Biochem J 439: 249-255, 2011.

8. Bubenik JL and Driscoll DM. Altered RNA binding activity underlies abnormal thyroid hormone metabolism linked to a mutation in selenocysteine insertion sequencebinding protein 2. J Biol Chem 282: 34653-34662, 2007.

9. Budiman ME, Bubenik JL, Miniard AC, Middleton LM, Gerber CA, Cash A, and Driscoll DM. Eukaryotic initiation factor $4 \mathrm{a} 3$ is a selenium-regulated RNA-binding protein that selectively inhibits selenocysteine incorporation. Mol Cell 35: 479-489, 2009.

10. Caban K, Kinzy SA, and Copeland PR. The L7Ae RNA binding motif is a multifunctional domain required for the ribosome-dependent Sec incorporation activity of Sec insertion sequence binding protein 2. Mol Cell Biol 27: 6350 6360, 2007.

11. Carlson BA, Moustafa ME, Sengupta A, Schweizer U, Shrimali R, Rao M, Zhong N, Wang S, Feigenbaum L, Lee BJ, Gladyshev VN, and Hatfield DL. Selective restoration of the selenoprotein population in a mouse hepatocyte selenoproteinless background with different mutant selenocysteine tRNAs lacking Um34. J Biol Chem 282: 3259132602, 2007.

12. Carlson BA, Novoselov SV, Kumaraswamy E, Lee BJ, Anver MR, Gladyshev VN, and Hatfield DL. Specific excision of the selenocysteine tRNA[Ser]Sec (Trsp) gene in mouse liver demonstrates an essential role of selenoproteins in liver function. J Biol Chem 279: 8011-8017, 2004.

13. Carlson BA, Xu XM, Gladyshev VN, and Hatfield DL. Selective rescue of selenoprotein expression in mice lacking a highly specialized methyl group in selenocysteine tRNA. J Biol Chem 280: 5542-5548, 2005.

14. Chavatte L, Brown BA, and Driscoll DM. Ribosomal protein L30 is a component of the UGA-selenocysteine recoding machinery in eukaryotes. Nat Struct Mol Biol 12: 408-416, 2005.

15. Chiu-Ugalde J, Theilig F, Behrends T, Drebes J, Sieland C, Subbarayal P, Köhrle J, Hammes A, Schomburg L, and Schweizer U. Mutation of megalin leads to urinary loss of selenoprotein $\mathrm{P}$ and selenium deficiency in serum, liver, kidneys and brain. Biochem J 431: 103-111, 2010.

16. Conrad $\mathrm{M}$ and Schweizer U. Unveiling the molecular mechanisms behind selenium-related diseases through knockout mouse studies. Antioxid Redox Signal 12: 851865, 2010.

17. Copeland PR, Fletcher JE, Carlson BA, Hatfield DL, and Driscoll DM. A novel RNA binding protein, SBP2, is required for the translation of mammalian selenoprotein mRNAs. EMBO J 19: 306-314, 2000.

18. Donovan J, Caban K, Ranaweera R, Gonzalez-Flores JN, and Copeland PR. A novel protein domain induces high affinity selenocysteine insertion sequence binding and elongation factor recruitment. J Biol Chem 283: 3512935139, 2008.

19. Donovan J and Copeland PR. Evolutionary history of selenocysteine incorporation from the perspective of SECIS binding proteins. BMC Evol Biol 9: 229, 2009.

20. Dumitrescu AM, Di Cosmo C, Liao XH, Weiss RE, and Refetoff S. The syndrome of inherited partial SBP2 deficiency in humans. Antioxid Redox Signal 12: 905-920, 2010.

21. Dumitrescu AM, Liao XH, Abdullah MS, Lado-Abeal J, Majed FA, Moeller LC, Boran G, Schomburg L, Weiss RE, and Refetoff S. Mutations in SECISBP2 result in abnormal 
thyroid hormone metabolism. Nat Genet 37: 1247-1252, 2005.

22. Fagegaltier D, Hubert N, Yamada K, Mizutani T, Carbon P, and Krol A. Characterization of mSelB, a novel mammalian elongation factor for selenoprotein translation. $E M B O$ $J$ 19: 4796-4805, 2000.

23. Handy DE, Hang G, Scolaro J, Metes N, Razaq N, Yang Y, and Loscalzo J. Aminoglycosides decrease glutathione peroxidase-1 activity by interfering with selenocysteine incorporation. J Biol Chem 281: 3382-3388, 2006.

24. Hatfield DL, Carlson BA, Xu XM, Mix H, and Gladyshev VN. Selenocysteine incorporation machinery and the role of selenoproteins in development and health. Prog Nucleic Acid Res Mol Biol 81: 97-142, 2006.

25. Hill KE, Wu S, Motley AK, Stevenson TD, Winfrey VP, Capecchi MR, Atkins JF, and Burk RF. Production of selenoprotein P (Sepp1) by hepatocytes is central to selenium homeostasis. J Biol Chem 287: 40414-40424, 2012.

26. Holmgren A and Björnstedt M. Thioredoxin and thioredoxin reductase. Methods Enzymol 252: 199-208, 1995.

27. Imai H, Hirao F, Sakamoto T, Sekine K, Mizukura Y, Saito M, Kitamoto T, Hayasaka M, Hanaoka K, and Nakagawa Y. Early embryonic lethality caused by targeted disruption of the mouse PHGPx gene. Biochem Biophys Res Commun 305: 278-286, 2003.

28. Jakupoglu C, Przemeck GK, Schneider M, Moreno SG, Mayr N, Hatzopoulos AK, de Angelis MH, Wurst W, Bornkamm GW, Brielmeier M, and Conrad M. Cytoplasmic thioredoxin reductase is essential for embryogenesis but dispensable for cardiac development. Mol Cell Biol 25: 1980-1988, 2005.

29. Kryukov GV, Castellano S, Novoselov SV, Lobanov AV, Zehtab O, Guigo R, and Gladyshev VN. Characterization of mammalian selenoproteomes. Science 300: 1439-1443, 2003.

30. Latrèche L, Jean-Jean O, Driscoll DM, and Chavatte L. Novel structural determinants in human SECIS elements modulate the translational recoding of UGA as selenocysteine. Nucleic Acids Res 37: 5868-5880, 2009.

31. Leinfelder W, Forchhammer K, Veprek B, Zehelein E, and Böck A. In vitro synthesis of selenocysteinyl-tRNA(UCA) from seryl-tRNA(UCA): involvement and characterization of the selD gene product. Proc Natl Acad Sci U S A 87: 543-547, 1990.

32. Lu J, Zhong L, Lonn ME, Burk RF, Hill KE, and Holmgren A. Penultimate selenocysteine residue replaced by cysteine in thioredoxin reductase from selenium-deficient rat liver. FASEB J 23: 2394-2402, 2009.

33. Miniard AC, Middleton LM, Budiman ME, Gerber CA, and Driscoll DM. Nucleolin binds to a subset of selenoprotein mRNAs and regulates their expression. Nucleic Acids Res 38: 4807-4820, 2010.

34. Moghadaszadeh B, Petit N, Jaillard C, Brockington M, Roy SQ, Merlini L, Romero N, Estournet B, Desguerre I, Chaigne D, Muntoni F, Topaloglu H, and Guicheney P. Mutations in SEPN1 cause congenital muscular dystrophy with spinal rigidity and restrictive respiratory syndrome. Nat Genet 29: 17-18, 2001.

35. Moriarty PM, Reddy CC, and Maquat LE. Selenium deficiency reduces the abundance of mRNA for Se-dependent glutathione peroxidase 1 by a UGA-dependent mechanism likely to be nonsense codon-mediated decay of cytoplasmic mRNA. Mol Cell Biol 18: 2932-2939, 1998.
36. Renko K, Werner M, Renner-Muller I, Cooper TG, Yeung CH, Hollenbach B, Scharpf M, Köhrle J, Schomburg L, and Schweizer U. Hepatic selenoprotein P (SePP) expression restores selenium transport and prevents infertility and motor-incoordination in Sepp-knockout mice. Biochem $J$ 409: 741-749, 2008.

37. Schneider M, Forster H, Boersma A, Seiler A, Wehnes H, Sinowatz F, Neumuller C, Deutsch MJ, Walch A, Hrabe d A, Wurst W, Ursini F, Roveri A, Maleszewski M, Maiorino M, and Conrad M. Mitochondrial glutathione peroxidase 4 disruption causes male infertility. FASEB J 23: 3233-3242, 2009.

38. Schneider MJ, Fiering SN, Pallud SE, Parlow AF, St Germain DL, and Galton VA. Targeted disruption of the type 2 selenodeiodinase gene (DIO2) results in a phenotype of pituitary resistance to T4. Mol Endocrinol 15: 2137-2148, 2001.

39. Schneider MJ, Fiering SN, Thai B, Wu SY, St Germain E, Parlow AF, St Germain DL, and Galton VA. Targeted disruption of the type 1 selenodeiodinase gene (Dio1) results in marked changes in thyroid hormone economy in mice. Endocrinology 147: 580-589, 2006.

40. Schoenmakers E, Agostini M, Mitchell C, Schoenmakers N, Papp L, Rajanayagam O, Padidela R, Ceron-Gutierrez L, Doffinger R, Prevosto C, Luan J, Montano S, Lu J, Castanet M, Clemons N, Groeneveld M, Castets P, Karbaschi M, Aitken S, Dixon A, Williams J, Campi I, Blount M, Burton H, Muntoni F, O'Donovan D, Dean A, Warren A, Brierley C, Baguley D, Guicheney P, Fitzgerald R, Coles A, Gaston H, Todd P, Holmgren A, Khanna KK, Cooke M, Semple R, Halsall D, Wareham N, Schwabe J, Grasso L, Beck-Peccoz P, Ogunko A, Dattani M, Gurnell M, and Chatterjee K. Mutations in the selenocysteine insertion sequence-binding protein 2 gene lead to a multisystem selenoprotein deficiency disorder in humans. J Clin Invest 120: 4220-4235, 2010.

41. Schomburg L, Schweizer U, Holtmann B, Flohe L, Sendtner M, and Köhrle J. Gene disruption discloses role of selenoprotein $\mathrm{P}$ in selenium delivery to target tissues. Biochem J 370: 397-402, 2003.

42. Schweizer U, Dehina N, and Schomburg L. Disorders of selenium metabolism and selenoprotein function. Curr Opin Pediatr 23: 429-435, 2011.

43. Schweizer U, Streckfuss F, Pelt P, Carlson BA, Hatfield DL, Köhrle J, and Schomburg L. Hepatically derived selenoprotein $\mathrm{P}$ is a key factor for kidney but not for brain selenium supply. Biochem J 386: 221-226, 2005.

44. Seeher S, Mahdi Y, and Schweizer U. Post-transcriptional control of selenoprotein biosynthesis. Curr Protein Pept Sci 13: 337-346, 2012.

45. Seiler A, Schneider M, Forster H, Roth S, Wirth EK, Culmsee C, Plesnila N, Kremmer E, Radmark O, Wurst W, Bornkamm GW, Schweizer U, and Conrad M. Glutathione peroxidase 4 senses and translates oxidative stress into 12/ 15-lipoxygenase dependent- and AIF-mediated cell death. Cell Metab 8: 237-248, 2008.

46. Sengupta A, Carlson BA, Weaver JA, Novoselov SV, Fomenko DE, Gladyshev VN, and Hatfield DL. A functional link between housekeeping selenoproteins and phase II enzymes. Biochem J 413: 151-161, 2008.

47. Shen Q, Fan L, and Newburger PE. Nuclease sensitive element binding protein 1 associates with the selenocysteine insertion sequence and functions in mammalian selenoprotein translation. J Cell Physiol 207: 775-783, 2006. 
48. Shen Q, Wu R, Leonard JL, and Newburger PE. Identification and molecular cloning of a human selenocysteine insertion sequence-binding protein. A bifunctional role for DNA-binding protein B. J Biol Chem 273: 5443-5446, 1998.

49. Shi ZZ, Osei-Frimpong J, Kala G, Kala SV, Barrios RJ, Habib GM, Lukin DJ, Danney CM, Matzuk MM, and Lieberman MW. Glutathione synthesis is essential for mouse development but not for cell growth in culture. Proc Natl Acad Sci U S A 97: 5101-5106, 2000.

50. Squires JE, Stoytchev I, Forry EP, and Berry MJ. SBP2 binding affinity is a major determinant in differential selenoprotein mRNA translation and sensitivity to nonsensemediated decay. Mol Cell Biol 27: 7848-7855, 2007.

51. Srinivasan G, James CM, and Krzycki JA. Pyrrolysine encoded by UAG in Archaea: charging of a UAG-decoding specialized tRNA. Science 296: 1459-1462, 2002.

52. Streckfuss F, Hamann I, Schomburg L, Michaelis M, Sapin R, Klein MO, Köhrle J, and Schweizer U. Hepatic deiodinase activity is dispensable for the maintenance of normal circulating thyroid hormone levels in mice. Biochem Biophys Res Commun 337: 739-745, 2005.

53. Sunde RA, Raines AM, Barnes KM, and Evenson JK. Selenium status highly regulates selenoprotein mRNA levels for only a subset of the selenoproteins in the selenoproteome. Biosci Rep 29: 329-338, 2009.

54. Walczak R, Westhof E, Carbon P, and Krol A. A novel RNA structural motif in the selenocysteine insertion element of eukaryotic selenoprotein mRNAs. RNA 2: 367379, 1996.

55. Winkler R, Benz V, Clemenz M, Bloch M, Foryst-Ludwig A, Wardat S, Witte N, Trappiel M, Namsolleck P, Mai K, Spranger J, Matthias G, Roloff T, Truee O, Kappert K, Schupp M, Matthias P, and Kintscher U. Histone deacetylase 6 (HDAC6) is an essential modifier of glucocorticoid-induced hepatic gluconeogenesis. Diabetes 61: 513-523, 2012.

56. Wu R, Shen Q, and Newburger PE. Recognition and binding of the human selenocysteine insertion sequence by nucleolin. J Cell Biochem 77: 507-516, 2000.

57. Xu XM, Carlson BA, Mix H, Zhang Y, Saira K, Glass RS, Berry MJ, Gladyshev VN, and Hatfield DL. Biosynthesis of selenocysteine on its tRNA in eukaryotes. PLoS Biol 5: e4, 2007.

58. Xu XM, Turanov AA, Carlson BA, Yoo MH, Everley RA, Nandakumar R, Sorokina I, Gygi SP, Gladyshev VN, and Hatfield DL. Targeted insertion of cysteine by decoding UGA codons with mammalian selenocysteine machinery. Proc Natl Acad Sci U S A 107: 21430-21434, 2010.

59. Yant LJ, Ran Q, Rao L, Van Remmen H, Shibatani T, Belter JG, Motta L, Richardson A, and Prolla TA. The selenoprotein GPX4 is essential for mouse development and protects from radiation and oxidative damage insults. Free Radic Biol Med 34: 496-502, 2003.
60. Yuan J, Palioura S, Salazar JC, Su D, O’ Donoghue P, Hohn MJ, Cardoso AM, Whitman WB, and Söll D. RNA-dependent conversion of phosphoserine forms selenocysteine in eukaryotes and archaea. Proc Natl Acad Sci U S A 103: 18923-18927, 2006.

61. Zinoni F, Birkmann A, Leinfelder W, and Böck A. Cotranslational insertion of selenocysteine into formate dehydrogenase from Escherichia coli directed by a UGA codon. Proc Natl Acad Sci U S A 84: 3156-3160, 1987.

Address correspondence to: Dr. Ulrich Schweizer Institut für Biochemie und Molekularbiologie Rheinische Friedrich-Wilhelms-Universität Nussallee 11 53115 Bonn Germany

E-mail: uschweiz@uni-bonn.de

Date of first submission to ARS Central, April 9, 2013; date of final revised submission, November 15, 2013; date of acceptance, November 25, 2013.

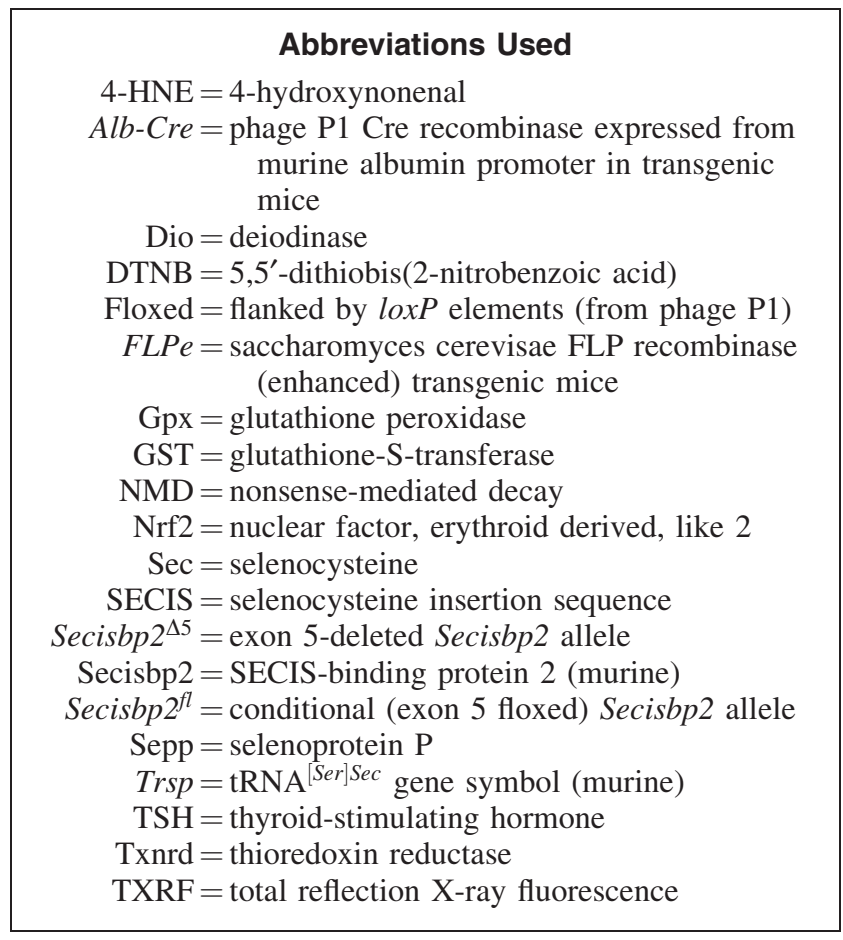

